\title{
Grey zone between narcolepsy type 1 and type 2
}

Zona cinzenta entre narcolepsia tipo 1 e tipo 2

Dear Editor,

The third International Classification of Sleep Disorders (ICSD-3) defines narcolepsy as patients with periods of sleep attacks or excessive daytime sleepiness. Neurophysiology tests with unremarkable polysomnography and positive Multiple Sleep Latency Test scores establish the diagnosis of narcolepsy ${ }^{1}$.

The difficulties in the differential diagnosis include secondary causes of excessive daytime sleepiness, narcolepsy, and other primary central hypersomnia disorders ${ }^{1}$. Usually, narcolepsy type 1 is differentiated by the presence of immunological pathophysiology and the consequent lower levels of hypocretin- $1^{2}$.

Usually, narcolepsy type 1 patients have cataplexy and a CSF hypocretin-1 concentration $\leq 110 \mathrm{pg} / \mathrm{mL}$ or $<1 / 3$ of mean values obtained in normal volunteers. ${ }^{2}$ Interestingly, the ICSD-3 defines patients with excessive daytime sleepiness and lower CSF hypocretin-1 levels as having type 1 narcolepsy, even without cataplexy. In fact, measuring CSF levels of hypocretin-1 has been considered the best option for the diagnosis of type 1 narcolepsy ${ }^{1}$.

However, the normal levels of hypocretin-1 are higher than $200 \mathrm{pg} / \mathrm{mL}^{2}$. Indeed, there is a grey zone between $110 \mathrm{pg} / \mathrm{mL}$ and $200 \mathrm{pg} / \mathrm{mL}$ that is not discussed in the literature.

We describe three patients with hypocretin-1 levels between $110 \mathrm{pg} / \mathrm{mL}$ and $200 \mathrm{pg} / \mathrm{mL}$ (Table). All had the presence of allele HLA-DQB1*0602, sleep hallucinations, and sleep paralysis. Two patients had all the criteria for narcolepsy type 1, but one of them did not have all the criteria for narcolepsy.

The hypocretin-1 threshold of $110 \mathrm{pg} / \mathrm{mL}$ has been identified by two studies ${ }^{2}$. Quality Receiver Operating Characteristic curve analysis indicates a threshold of $200 \mathrm{pg} / \mathrm{mL}$ and $150 \mathrm{mg} / \mathrm{mL}$ for direct and extracted assays in volunteers, respectively ${ }^{3,4}$. Although the biomarkers for identification of type 1 narcolepsy are very useful, the identification of patients with narcolepsy type 2 is still a challenge in many cases.

A paper written by Barateau et al. entitled Comorbidity between central disorders of hypersomnolence and immune-based disorders, expands this discussion. ${ }^{5}$ They state that the prevalence of immune diseases, inflammatory disorders, and allergies are not higher in narcolepsy type 1. Interestingly, autoimmune diseases were higher in narcolepsy type 2 patients and inflammatory disorders were common in idiopathic hypersomnolence.

Clinical and neurophysiology characteristics, genetics and hypocretin-1 levels are not sufficient to define narcolepsy in all circumstances. Unfortunately, the description of a few patients cannot characterize a pattern, especially in atypical cases. Further efforts to study patients with hypocretin-1 between $110 \mathrm{pg} / \mathrm{mL}$ and $200 \mathrm{pg} / \mathrm{mL}$ should help to classify them. It is possible that, in the future, biomarkers of inflammation and immune responses will be useful for that.

Gustavo Bruniera Fernandes ${ }^{1}$, Renata Carvalho Cremaschi $^{1}$, SérgioTufik ${ }^{1}$, Fernando Morgadinho Coelho ${ }^{1,2}$

Table. Demographic, clinical, genetic, and hypocretin-1 characteristics.

\begin{tabular}{|c|c|c|c|c|c|c|c|c|c|}
\hline Age & HLA-DQB1*0602 & $\begin{array}{l}\text { CSF-HCRT } \\
(\mathrm{pg} / \mathrm{mL})\end{array}$ & $\begin{array}{l}\text { MSLT/Average } \\
\text { latency/(min) }\end{array}$ & MSLT/SOREMP & Cataplexy & $\begin{array}{c}\text { Sleep } \\
\text { paralysis }\end{array}$ & Hallucinations & $\begin{array}{c}\text { Automatic } \\
\text { behavior }\end{array}$ & $\begin{array}{c}\text { Disruptive } \\
\text { sleep }\end{array}$ \\
\hline 49 & Yes & 135.4 & 1 & 4 & Yes & Yes & Yes & No & Yes \\
\hline 23 & Yes & 139.49 & 4 & 1 & No & Yes & Yes & No & No \\
\hline 40 & Yes & 140.65 & 5 & 4 & Yes & Yes & Yes & No & Yes \\
\hline
\end{tabular}

CSF: cerebrospinal fluid; HCRT: hypocretin; MSLT: Multiple Sleep Latency Test; SOREMP: sleep onset rapid eye moment period; min: minutes.

${ }^{1}$ Univesidade Federal de São Paulo, Departamento de Psicobiologia, São Paulo SP, Brasil;

${ }^{2}$ Univesidade Federal de São Paulo, Departamento de Neurologia, São Paulo SP, Brasil.

Correspondence: Fernando Morgadinho Coelho; Rua Napoleão de Barros, 925 / $2^{\circ}$ andar, 04024-002 São Paulo SP, Brasil; E-mail:fernandomorgadinho@hotmail.com Conflict of interest: There is no conflict of interest to declare.

Received 07 March 2017; Accepted 31 March 2017. 


\section{References}

1. Ruoff C, Rye D. The ICSD-3 and DSM-5 guidelines for diagnosing narcolepsy: clinical relevance and practicality. Curr Med Res Opin. 2016:1-12.

2. Mignot E, Lammers GJ, Ripley B, Okun M, Nevsimalova S, Overeem $S$ et al. The role of cerebrospinal fluid hypocretin measurement in the diagnosis of narcolepsy and other hypersomnias. Arch Neurol. 2002;59(10):1553-62. https://doi.org/10.1001/archneur.59.10.1553

3. Nishino S, Ripley B, Overeem S, Lammers GJ, Mignot E. Hypocretin (orexin) deficiency in human narcolepsy. Lancet. 2000;355(9197):39-40. https://doi.org/10.1016/S0140-6736(99)05582-8
4

Nishino S, Ripley B, Overeem S, Nevsimalova S, Lammers GJ, Vankova $J$ et al. Low cerebrospinal fluid hypocretin (Orexin) and altered energy homeostasis in human narcolepsy Ann Neurol. 2001;50(3):381-8. https://doi.org/10.1002/ana.1130

5. Barateau L, Lopez R, Arnulf I, Lecendreux M, Franco P, Drouot X et al. Comorbidity between central disorders of hypersomnolence and immune-based disorders. Neurology. 2017;88(1):93-100. https://doi.org/10.1212/WNL.0000000000003432 